\title{
The Effect of Problem-Based Learning (PBL) Model On Mathematical Communication Skills of Junior High School Students - A Meta-Analysis Study
}

\author{
Nipa Susanti ${ }^{1}$, Dadang Juandi², Maximus Tamur ${ }^{3}$ \\ 1,2Departemen Pendidikan Matematika, Universitas Pendidikan Indonesia, Bandung, Indonesia \\ ${ }^{3}$ Pendidikan Matematika, Universitas Katolik Indonesia Santu Paulus Ruteng, Ruteng, Indonesia \\ 1nipasusanti95@gmail.com,2dadangdang.juandi@upi.edu, ${ }^{3}$ maximustamur@unikastpaulus.ac.id
}

\begin{tabular}{|c|c|}
\hline & ABSTRACT \\
\hline Article History: & \multirow{9}{*}{$\begin{array}{l}\text { This study aims to integrate research findings on the effect of the Problem-Based } \\
\text { Learning (PBL) model on the mathematical communication skills of junior high } \\
\text { school students in Indonesia since } 2014 \text {. The research method used is a meta- } \\
\text { analysis with many samples studied, namely } 12 \text { published articles. The sampling } \\
\text { technique used was purposive sampling. The effect size transformation is based } \\
\text { on the g hedge equation calculated using the Comprehensive Meta-Analysis } \\
\text { (CMA) application. Based on the results of the analysis, the combined effect of } \\
\text { PBL on mathematical communication skills is } 0.791 \text {, with the high influence } \\
\text { criteria according to the random-effect estimation model. There are four criteria } \\
\text { considered, namely, sample size, year of study, source of journal publication, and } \\
\text { grade level. The results of the heterogeneity test seen based on the variables } \\
\text { studied showed that the effect of the PBL learning model was not significantly } \\
\text { different from the three moderator variables in terms of sample size, year of } \\
\text { study, and publication journals and very different in terms of grade level. This } \\
\text { finding is surprising because the random-effects model, as determined by the } \\
\text { heterogeneity test, showed variation between effect sizes. Only one of the four } \\
\text { variables causes this variation. Therefore further research is needed, which } \\
\text { includes more studies and the characteristics studied to describe it more } \\
\text { accurately. }\end{array}$} \\
\hline Received : 17-07-2020 & \\
\hline Revised $1: 15-08-2020$ & \\
\hline Revised 2 : $13-09-2020$ & \\
\hline Accepted : 14-09-2020 & \\
\hline Online $\quad: 03-10-2020$ & \\
\hline Keywords: & \\
\hline $\begin{array}{l}\text { Meta-analysis; } \\
\text { Problem Based } \\
\text { Learning; } \\
\text { Communication Skills. }\end{array}$ & \\
\hline & \\
\hline
\end{tabular}

\begin{tabular}{cc}
\hline doi $\$$ Crossref & (c) (i) () \\
https://doi.org/10.31764/itam.v4i2.2481 & This is an open access article under the CC-BY-SA license \\
\hline
\end{tabular}

\section{A. INTRODUCTION}

One effort to improve the quality of human resources is the need for special attention to education. Education in this global era has transitioned to 21st-century skills. The abilities that must be possessed by students in the 21st century are the mathematical communication abilities of students. This 21st Century skill is implemented with the aim of responding to the demands of an increasingly competitive and growing era (Bolstad, 2020; Genc \& Erbas, 2019). Therefore, it is necessary to prepare the character of the skills students must possess in the process of education towards the 21st century for all levels of education and all subjects, including mathematics (Nahdi, 2019; Pradana et al., 2020). National Council Of Teacher Of Mathematics (2000) also mentioned that the general goal of learning mathematics is to develop students' ability to set 5 standards of the mathematics learning process, one of which 
is to convey ideas or communication. In fact, students are highly required to have good mathematical communication skills in learning and communicating it.

Problem-based learning (PBL) is a learning model that can lead students to get to know objects in mathematics, involve students in learning, so students become more active, and expose students to practical problems as a foothold of students in the learning process (Hafely et al., 2019; Sari \& Rahadi, 2014; Servant-Miklos, 2018; Thorndahl \& Stentoft, 2020). In PBL learning, learning is student-centered and makes students from passive listeners active. The problem presented is the student's starting point in learning material (Ali et al., 2010; Ferreira \& Trudel, 2012; Hidayati et al., 2020). PBL can optimize students' thinking abilities through group work processes so students can improve, hone, empower, and test their thinking abilities on an ongoing basis. In other words that PBL can facilitate the process of checking out students' answers in completing systematic and structured mathematical communication skills compared to conventional learning (Surya et al., 2018).

There are several studies that have examined the effect of PBL models on the mathematical communication skills of junior high school students (Sari \& Rahadi, 2014; Khamid \& Santosa, 2016; Yanti, 2017; Hidayat, 2018), but no research has been conducted to further evaluate the influence of the model PBL on mathematical communication skills. Previous studies have not yet carried out further research on study characteristics such as sample size, research years, journal publications, and levels of education that might also affect students' mathematical communication abilities. On the other hand, a comprehensive conclusion about the effect of the PBL model on mathematical communication skills is needed.

The effect of PBL models on mathematical communication skills cannot be investigated using only primary research, but the need for further research using meta-analysis. Metaanalysis is a quantitative analysis method used to organize and extract as much data as possible so as to produce more accurate and convincing information (Glass, 2015; Higgins \& Katsipataki, 2015; Siddaway et al., 2019). A meta-analysis study is required with the aim of integrating and interpreting the findings of both the overall study and the variables of the primary study (Tamur et al., 2020; Tamur \& Juandi, 2020).

Several meta-analysis studies have been conducted by Sarifah (2011) by examining the effectiveness of PBL on mathematics learning outcomes. Then, Demirel \& Dağyar (2016), Qin et al. (2016), Wang \& Lin (2009), Purwati et al. (2017), Rosli et al. (2014), and Kadir et al. (2013) have conducted a meta-analysis of the effects of PBL on competence in reasoning, communication, connection, and problem-solving, and its application in real-life contexts. Several other meta-analysis studies specifically discuss the effect of the PBL model on students' critical thinking skills (Anugraheni, 2018), logical, creative, and problem-solving skills (Asror, 2016), but there is no specific meta-analysis on the effect of PBL learning on mathematical communication skills. Students. Previous studies also did not explain which effect model was chosen to estimate the overall effect size. As a result, the overall effect size found to be concerned is overrepresented (Borenstein et al., 2009). This study complements the shortcomings of previous studies by finding the summary effect of the application of the PBL model on students' mathematical communication skills and analyzing the degree of variance of the primary studies so as to consider the implications. Thus, the researcher considers it necessary to test a meta-analysis of the effect of the PBL model on students' mathematical communication skills, namely by examining the following questions: 1) How does the PBL model influence students' mathematical communication skills?; 2) How does the PBL model influence students' mathematical communication skills in terms of the research sample size, research year, journal publication, and class level aspects?. 


\section{B. METHODS}

\section{Research design}

This study aims to draw a statistical conclusion from the results of research examining the effect of problem-based learning models on mathematical communication skills of junior high school students in Indonesia using the meta-analysis method. Meta-analysis is a set of quantitative techniques for combining evidence from several related studies (Cumming, 2012). The results obtained from the analysis are then converted to effect size. Effect size is a method used to find out how much a group is different from other groups. The research procedure is adjusted to the steps of a meta-analysis, namely: 1) Preparation stage, namely conducting research criteria; 2) The implementation phase, which is looking for and collecting studies and then calculating the effect of the license; 3) Data analysis stage, i.e., analyzing effect size based study characteristics (Syafrial, 2018; Tamur et al., 2020).

\section{Inclusion Criteria}

The inclusion criterion is the standard eligibility set in selecting primary studies, namely published research indexed by Google Scholar (https://scholar.google.com/), Portal Garuda (http://garuda.ristekbrin.go.id/), and Since and Technology Index (http://sinta.ristekbrin.go.id/journals). Studies that did not include a control class were excluded. This research is limited to the 2014-2019 study on the effect of PBL on students' mathematical communication skills. The descriptive statistics used in this study are the mean, standard deviation, and sample size of the experimental and control groups. Besides, other data needed are the source of publication and the year of research.

\section{Data Collection}

The research data collection was carried out by tracing the research results published in online journals. According to the inclusion criteria, the study search used the Google scholar database and the Garuda portal. The search strategy uses the keywords "Communication Skills Using Problem Based Learning Models" and "Communication Skills Using Problem Based Learning Models." This process provides a list of journals that have published related studies as in Table 1 below:

Table 1. List of Journals That Published Studies

\begin{tabular}{ccc}
\hline No & Journal Name & URL \\
\hline 1 & Jurnal Cendekia & $\begin{array}{c}\text { https://www.j- } \\
\text { cup.org/index.php/cendekia/article/download/30/23 }\end{array}$ \\
\hline 2 & $\begin{array}{c}\text { Seminar Nasional FST } \\
\text { https://conference.unikama.ac.id/artikel/index.php/senastek/articl } \\
\text { e/download/130/109 }\end{array}$ \\
\hline 3 & $\begin{array}{c}\text { Jurnal Serunai Ilmu } \\
\text { Pendidikan }\end{array}$ & https://www.ejournal.stkipbudidaya.ac.id/index.php/ja/article/vie \\
wFile/154/114
\end{tabular}


Based on Table 1, a list that publishes the effect of the PBL model on communication skills, ten journals are consisting of 5 journals, which consist of journals that have been indexed and those that are indexed by Google Scholar and Portal Garuda. The article is a journal that matches the inclusion criteria that have been determined by the research team and contains the data needed in the study. Then based on the journal publisher data above, studies are grouped based on the characteristics of the study understudy, as presented in Table 2 .

Table 2. Study Information

\begin{tabular}{ccc}
\hline Study characteristics & Group & Total \\
\hline \multirow{2}{*}{ Sample Size } & $>30$ & 8 \\
\cline { 2 - 3 } & $\leq 30$ & 4 \\
\cline { 2 - 3 } Research Year & $2014-2015$ & 2 \\
\cline { 2 - 3 } & $2016-2017$ & 3 \\
\cline { 2 - 3 } Journal Publication & $2018-2019$ & 7 \\
\cline { 2 - 3 } & Sinta Indexed & 7 \\
\hline \multirow{2}{*}{ Grade Level } & Not Indexed Sinta & 9 \\
\cline { 2 - 3 } & Grade VII & 7 \\
\hline
\end{tabular}

\section{Reliability Test}

The instrument in this study was conducted by coding the research that was made into the unit of analysis, the research team that made the coding. Thus the reliability between the makers of coding cannot be stated in this study. Although there are weaknesses in this study, the results of this meta-analysis reveal the true situation. One other weakness of the metaanalysis study is that there is a bias caused by the tendency of journals to publish only significant articles (Borenstein et al., 2009). As a result, the results of the meta-analysis tend to be over-interpreted and not reflect the actual conditions. To avoid this publication bias, funnel plots are used as in Figure 1 below:

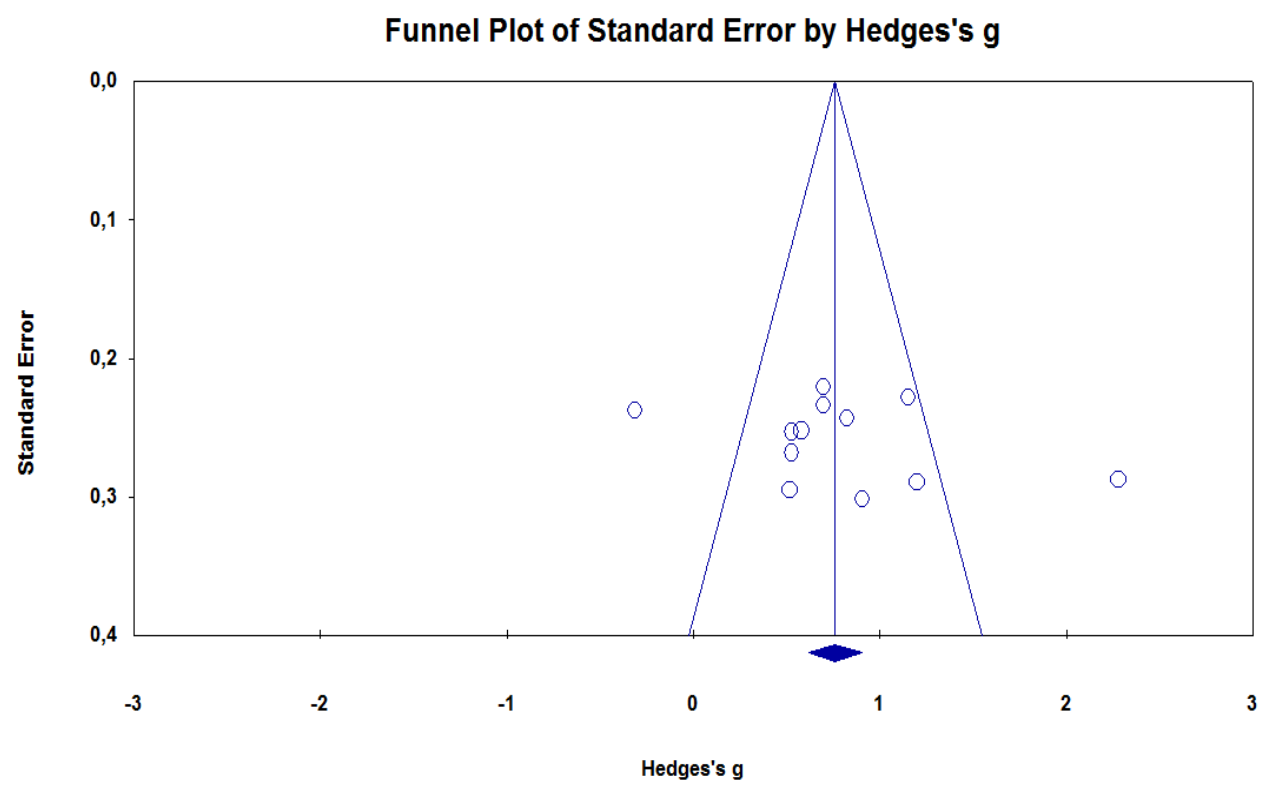

Figure 1. Funnel Plot

As explained in Figure 1, the effect size is spread almost symmetrically in the center of the funnel plot, but there are 2 data scattered on the left and right side of the funnel plot. However, based on the Fail Save N (FSN) calculation, the N Rosenthal value is 334. According to the 
formula $\mathrm{N} /(5 \mathrm{~K}+10)$ (Tamur et al., 2020) with a k value of 12 , it is obtained 334 / (5* $12+$ $10)=4,771$. According to this calculation, because the statistical calculation result is 4.7771> 1 , this meta-analysis is resistant to publication bias, and this research is reliable.

\section{Statistics Analysis}

The effect size transformation in each primary study is based on the Hedges'g equation. Calculation using Comprehensive Meta-analysis V.3 (CMA) software with the effect size criteria as in Table 3 (Glass et al., 1981). Then, the heterogeneity test between studies or between groups of variables was carried out by examining the $Q$ statistic between $(\mathrm{Qb})$ and $\mathrm{p}$ value. If the p-value is less than 0.05 , the null hypothesis, which states that the effect size of each study or group of variables is homogeneous, is rejected. Thus the estimation chosen is the random-effect model. If the p-value is more than 0.05 , then the null hypothesis is accepted, and the fixed-effect model is evaluated.

Table 3. Effect Size Criteria

\begin{tabular}{ccc}
\hline No & Interval & Criteria \\
\hline 1 & ES $\leq 0,15$ & negligible effect \\
\hline 2 & $0,15<E S \leq 0,40$ & small effect \\
\hline 3 & $0,40<E S \leq 0,75$ & medium effect \\
\hline 4 & $0,75<E S \leq 1,10$ & high effect \\
\hline 5 & $1,10<E S \leq 1,45$ & very high effect \\
\hline 6 & $E S>1,45$ & high influence \\
\hline
\end{tabular}

\section{RESULT AND DISCUSSION}

\section{Overall Analysis}

Based on the results of calculations using CMA software, the data is as shown in Table 4 below:

Table 4. Study Effect Size Categories

\begin{tabular}{cccc}
\hline Kode & Author & Effect Size & Category \\
\hline J01 & Hidayat (2018) & 0,903 & High Effect \\
\hline J02 & Kurniati (2019) & 0,581 & High Effect \\
\hline J03 & Sinaga and Santa (2018) & 0,699 & Medium Effect \\
\hline J04 & Sari, et al. (2019) & 0,525 & Medium Effect \\
\hline J05 & Kotrunada and Khaerudin (2019) & 0,698 & Medium Effect \\
\hline J06 & Yanti (2017) & 2,279 & Medium Effect \\
\hline J07 & Oktaviani dan Mukhni (2019) & 1,199 & High Influence \\
\hline J08 & Mawartika (2017) & 0,528 & Very High Effect \\
\hline J09 & Fauziah (2018) & 0,825 & Medium Effect \\
\hline J10 & Khamid and Rusgianto (2016) & $-0,314$ & High Effect \\
\hline J11 & Sari and Moersetyo (2014) & 1,150 & Negligible Effect \\
\hline J12 & Triana et al. (2014) & 0,518 & High Effect \\
\hline & ES combined & $\mathbf{0 , 7 9 1}$ & High Effect
\end{tabular}

Table 4 . obtained the effect size range obtained from 12 studies, namely $(-0.314)-2,279$. From these data, 1 study showed negligible effects, and six studies showed Medium Effects, 3 High Effect studies, 1 Very High Effect study, and 1 High Influence study. The results of the analysis are still based on permanent effects. Broadly speaking, the comparison of metaanalysis results according to the effect model is presented in Table 5 below: 
Table 5. Analysis Results Based on the Effect Model

\begin{tabular}{|c|c|c|c|c|c|c|c|c|c|}
\hline \multirow{2}{*}{ Model } & \multirow{2}{*}{$\mathbf{n}$} & \multirow{2}{*}{ ES } & \multirow{2}{*}{$\mathbf{P}$} & \multirow{2}{*}{ Qb } & \multirow{2}{*}{$I^{2}$} & \multirow{2}{*}{$\mathbf{Z}$} & \multirow{2}{*}{$\begin{array}{l}\text { Standard } \\
\text { Error }\end{array}$} & \multicolumn{2}{|c|}{$\begin{array}{l}\text { 95\% Confidence } \\
\text { Interval }\end{array}$} \\
\hline & & & & & & & & $\begin{array}{l}\text { Lower } \\
\text { limit }\end{array}$ & $\begin{array}{l}\text { Upper } \\
\text { Limit }\end{array}$ \\
\hline Fixed & 12 & 0,760 & 0,000 & \multirow{2}{*}{56,776} & \multirow{2}{*}{80,625} & 10,316 & 0,074 & 0,615 & 0,904 \\
\hline Random & 12 & 0,791 & 0,000 & & & 4,702 & 0,168 & 0,461 & 1,120 \\
\hline
\end{tabular}

From Table 5 above, a P-value of $<0.05$ means that there are significant differences between the studies studied, so random-effects are used. Based on the random-effects model, the lower limit is 0.641 , and the upper limit is 1.120 , with a $95 \%$ confidence interval. Whereas based on the fixed-effects model, the lower limit is 0.615 , and the upper limit is 0.904 , with a $95 \%$ confidence interval.

From the following Table 5, based on the results of the random-effect statistics, the great effect of PBL learning on mathematical communication skills shows a combined effect size value of 0.791 with high effect criteria. This means that the PBL model has a high effect on the mathematical communication skills of junior high school students. The results of this analysis show results that are consistent with research conducted by (Asror, 2016) which states that the PBL model gives a High Effect to students at the junior high school level.

\section{Analysis Based on Study Character}

Further analysis is carried out to answer the research questions. Of the 12 studies observed by researchers, they were grouped according to sample size, research year, and publication journals so that a summary was obtained as in Table 6 below:

Table 6. Analysis Results Based on Study Characteristics

\begin{tabular}{|c|c|c|c|c|c|c|c|c|}
\hline \multirow{2}{*}{$\begin{array}{l}\text { Characteristic } \\
\text { of the study }\end{array}$} & \multirow{2}{*}{ Group } & \multirow{2}{*}{\multicolumn{2}{|c|}{$\begin{array}{l}\text { Number } \\
\text { of Studies }\end{array}$}} & \multicolumn{2}{|c|}{$\begin{array}{c}\text { Test of null (2- } \\
\text { tail) }\end{array}$} & \multicolumn{3}{|c|}{ Heterogeneity } \\
\hline & & & & $\mathbf{Z}$ & p & Qb & Df(Q) & $\mathbf{P}$ \\
\hline \multirow{2}{*}{ Sample Size } & $\leq 30$ & 4 & 0,776 & 5,395 & 0,000 & \multirow{2}{*}{0,018} & \multirow{2}{*}{1} & \multirow{2}{*}{0,894} \\
\hline & $>30$ & 8 & 0,754 & 8,794 & 0,000 & & & \\
\hline \multirow{3}{*}{ Research Year } & $2014-2015$ & 2 & 0,913 & 5,057 & 0,000 & \multirow{3}{*}{1,113} & \multirow{3}{*}{2} & \multirow{3}{*}{0,573} \\
\hline & $2016-2017$ & 3 & 0,667 & 4,496 & 0,000 & & & \\
\hline & $2018-2019$ & 7 & 0,775 & 7,858 & 0,000 & & & \\
\hline \multirow[b]{2}{*}{$\begin{array}{c}\text { Journal } \\
\text { Publication }\end{array}$} & Sinta Indexed & 5 & 0,885 & 7,755 & 0,000 & \multirow[b]{2}{*}{2,051} & \multirow[b]{2}{*}{1} & \multirow[b]{2}{*}{0,152} \\
\hline & $\begin{array}{l}\text { Not Indexed } \\
\text { Sinta }\end{array}$ & 7 & 0,671 & 6,952 & 0,000 & & & \\
\hline \multirow{2}{*}{ Grade Level } & Grade VII & 3 & 1,219 & 7,499 & 0,000 & \multirow{2}{*}{9,699} & \multirow{2}{*}{1} & \multirow{2}{*}{0,002} \\
\hline & Grade VIII & 9 & 0,647 & 7,743 & 0,000 & & & \\
\hline
\end{tabular}

Based on the sample size contained in Table 6 above, for the sample size $\leq 30$, the effect size value is obtained 0.776 , whereas if the sample size $>30$ is obtained, the effect size value 0.754 with both categories the High Effect. However, if seen from the statistical value of the effect of the license, when the sample size is $\leq 30$, the value of the effect of the vaccine is higher. Based on the heterogeneity test in Table 6, the statistical value of $\mathrm{Qb}$ obtained as a result of the homogeneity test based on the sample size variable shows the result of 0.018 , while the publication journal base shows the $\mathrm{Qb}$ statistical value of 2.051. The statistical value is smaller than the QTable value of 3.841 at the $95 \%$ confidence interval and the significance level of 0.05. This means that the effect of PBL on mathematical communication skills of junior high school students does not differ significantly based on sample size. These findings are no different from Kadir et al., (2013), which states that the effectiveness of treatment is not 
determined by sample size but the results of this study differ from (Bayir \& Bozkurt, 2018; Tamur et al., 2020) who find the $Q b>$ Qtable statistics which means there are differences that significant in effect size between groups according to sample size. This difference in results is an issue that can be further investigated.

In terms of research years, the results of the analysis show that in 2014-2019 the effect size is greater than in the years after. In 2014 - 2019, the effect size value was 0.193 , and in 2018-2018 the value of the effect size was 0.667 with both criteria, High Effect, while in 2016 - 2017, the value of the effect was 0.667 with the Medium Effect criterion. Based on the year of research, the statistical value of $\mathrm{Qb}$ is 1.113, which is smaller than the QTable with a 95\% confidence interval and a significant level of $0.05,5.991$, which means that the effect of PBL on the mathematical communication ability of junior high school students is not significantly different based on the research year and the findings are consistent with the research (Bayir \& Bozkurt, 2018; Tamur et al. 2020; Tamur \& Juandi, 2020).

From Table 6, the statistical results are obtained when viewed from the source of its publication journal, and the Sinta indexed study shows a higher result, which is 0.885 with High Effect compared to the non-indexed study with a statistical value of 0.671 , which shows the sedan effect. Based on the obtained Qb statistical value of 2.051 results and showed smaller results compared with the QTable value of 3.841 at a $95 \%$ confidence interval and a significance level of 0.05 , meaning that the effect of PBL on the mathematical communication ability of junior high school students did not differ significantly based on publication journals and was consistent with findings research Tamur et al., (2020). According to the results of the analysis in Table 6 , the value of effect size was obtained in a study conducted in grade VII of 1,219 with Very High Effect criteria, while in grade VIII, a statistical value of 0.647 was obtained with Medium Effect criteria. The statistical value of $Q b>$ QTable is 9,699>3,841, with a confidence interval of $95 \%$ and a significant level of 0.05 , which means that the effect of PBL on the mathematical communication skills of junior high school students is significantly different in terms of aspects of the grade level.

This meta-analysis was carried out to investigate the effect of PBL learning on the mathematical abilities of junior high school students. The results of a meta-analysis in this study show that overall, this PBL model has a high effect on the communication skills of junior high school students. This finding is consistent with the results of previous meta-analysis studies such as those conducted by Rosli et al. (2014) and Qin et al. (2016) with a combined effect size of 0.748 each; 0.76 ; and 0.76 . The researchers conducted a meta-analysis to examine the effectiveness of PBL on student achievement. Although they did not specifically conduct a meta-analysis study on students' mathematical communication skills, these findings suggest a similar overall trend. However, other meta-analyses show slightly different results, as reported by Demirel \& Dağyar (2016), where the combined effect size is 0.44 . This difference in results belongs to the need to be further investigated by involving more studies that are analyzed to examine the reasons for the differences.

\section{CONCLUSION AND SUGGESTIONS}

The analysis results based on the random-effect estimation model showed that the overall effect size of PBL use on students' mathematical communication skills was 0.791 (95\% confidence interval, and 0.168 standard error). Based on the characteristics of the study, in terms of sample size, if the sample size is $\leq 30$ students, the value of the effect of the trial is higher than that of the sample size> 30, reviewed based on the research year, in 2014-2019 the statistical value is higher compared to the year afterward. Then based on the published journals, studies studied and indexed sinta have higher statistical values when compared to studies that are not indexed and based on grade levels, in grade VII show a statistically larger effect size value than in grade VIII. However, when viewed from a heterogeneity test, the 
effect of PBL on communication skills did not differ significantly based on aspects of sample size, research years and publication journals, and there were significant differences when viewed from aspects of grade level. This research has not fully reflected the effect of PBL learning on the mathematical communication skills of junior high school students, so that in the future it is necessary to have more research containing the study under study and add to the characteristics studied in order to achieve the desired target. Future researchers can use this research as a reference for continuing broader research than previous research.

\section{ACKNOWLEDGMENT}

We would like to thank the primary authors for providing the information we needed in this study.

\section{REFERENCES}

Ali, R., Hukamdad, D., Akhter, A., \& Khan, A. (2010). Effect of Using Problem Solving Method in Teaching Mathematics on the Achievement of Mathematics Students. Asian Social Science, 6(2), 67-72. https://doi.org/10.5539/ass.v6n2p67

Anugraheni, I. (2018). Meta Analisis Model Pembelajaran Problem Based Learning dalam Meningkatkan Keterampilan Berpikir Kritis di Sekolah Dasar. Polygot, 14(1), 9-18. http://dx.doi.org/10.19166/pji.v14i1.789

Asror, A. H. (2016). Meta-Analisis: PBL. PRISMA Prosiding Seminar Nasional Matematika, 508-513. https://journal.unnes.ac.id/sju/index.php/prisma/article/download/21682/10309

Bayir, O. G., \& Bozkurt, M. (2018). Effectiveness of Cooperative Learning Approaches Used in the Course of Social Studies in Turkey: A Meta-Analysis Study. Online Submission, 4(10), 171-192. https://doi.org/10.5281/zenodo.1313863

Bolstad, O. H. (2020). Secondary teachers ' operationalisation of mathematical literacy. European Journal of Science and Mathematics Education, 8(3), 115-135.

Borenstein, M., Hedges, L. V, \& Rothstein, H. R. (2009). Introductionto Meta-Analysis (Issue January). John Wiley \& Sons.

Cumming, G. (2012). Understanding The New Statistics. https://tandfbis.s3.amazonaws.com/rtmedia/pp/common/sample-chapters/9780415879682.pdf

Demirel, M., \& Dağyar, M. (2016). Effects of Problem-Based Learning on Attitude: A Meta-analysis Stud. EURASIA Journal of Mathematics, Science \& Technology Education, 12(8), 2115-2137. https://doi.org/10.12973/eurasia.2016.1293a

Ferreira, M., \& Trudel, A. (2012). Tje Impsct of Problem Based Learning (PBL) on Student Attitudes Toward Science, Problem-Solving Skills, and Sense of Community in the Classroom. Journal of Classroom Interaction, 47(1), 23-30. https://eric.ed.gov/?id=EJ974653

Genc, M., \& Erbas, A. K. (2019). Secondary mathematics teachers' conceptions of mathematical literacy. International Journal of Education in Mathematics, Science and Technology, 7(3), 222-237.

Glass, G. V. (2015). Meta-analysis at middle age: A personal history. Research Synthesis Methods, 6(3), 221-231. https://doi.org/10.1002/jrsm.1133

Glass, G. V, McGaw, B., \& Smith, M. L. (1981). Meta-Analysis in Social Research. Beverly Hills, CA: Sage, 2982.

Hafely, Bey, A., Jazuli, L. O. A., \& Sumarna, N. (2019). Pengaruh Model Pembelajaran Problem Based Learning (PBL) Terhadap Kemampuan Komunikasi Matematik Siswa SMP. Jurnal Pendidikan Matematika, 9(2), 194. https://doi.org/10.36709/jpm.v9i2.5869

Hidayat, A. (2018). Pengaruh Model Pembelajaran Berbasis Masalah Dengan Pendekatan Pemecahan Masalah Terhadap Kemampuan Komunikasi Matematis Siswa Smp Negeri 1 Rumbio Jaya. Jurnal Cendekia: Jurnal Pendidikan Matematika, 2(1), 23-40. https://doi.org/10.31004/cendekia.v2i1.30

Hidayati, Abidin, Z., \& Ansari, B. I. (2020). Improving students' mathematical communication skills and learning interest through problem based learning model. Journal of Physics: Conference Series, 1460(1). https://doi.org/10.1088/1742-6596/1460/1/012047

Higgins, S., \& Katsipataki, M. (2015). Evidence from meta-analysis about parental involvement in 
education which supports their children's learning. Journal of Children's Services, 10(3), 280-290. https://doi.org/10.1108/JCS-02-2015-0009

Kadir, Milama, B., \& Khairunnisa. (2013). Meta-Analisis Efektivitas Pendekatan Problem Solving Dalam Pembelajaran Sains dan Matematika. In Lembaga Penelitian UIN Syarif Hidayatullah Jakarta. Lembaga Penelitian UIN Syarif Hidayatullah Jakarta. https://doi.org/10.1017/CB09781107415324.004

Khamid, A., \& Santosa, R. H. (2016). Keefektifan pendekatan PBL dan CTL ditinjau dari komunikasi matematis dan motivasi belajar siswa SMP. PYTHAGORAS: Jurnal Pendidikan Matematika, 11(2), 111. https://doi.org/10.21831/pg.v11i2.10660

Nahdi, D. S. (2019). Keterampilan Matematika Di Abad 21. Jurnal Cakrawala Pendas, 5(2), 133-140. https://doi.org/10.31949/jcp.v5i2.1386

NCTM. (2000). Principles for School Mathematics. Reston: National Council of Teacher of Mathematics. https://www.nctm.org/uploadedFiles/Standards_and_Positions/PSSM_ExecutiveSummary.pdf

Pradana, L. N., Sholikhah, O. H., Maharani, S., \& Kholid, M. N. (2020). Virtual mathematics kits (VMK): Connecting digital media to mathematical literacy. International Journal of Emerging Technologies in Learning, 3, 234-241. https://doi.org/10.3991/ijet.v15i03.11674

Purwati, H., Wuri, D. E., Nugroho, A. A., \& Dwijayanti, I. (2017). Meta Analisis Pengaruh Model Pembelajaran Kolaboratif dan Kompetitif di Jawa Tengah dalam Tiga Tahun Terakhir. Seminar Nasional Matematika dan Pendidikan Matematika (2nd SENATIK), 465-470.

Qin, Y., Wang, Y., \& Floden, R. E. (2016). The Effect of Problem-Based Learning on Improvement of the Medical Educational Environment: A Systematic Review and Meta-Analysis. Medical Principles and Practice, 25(6), 525-532. https://doi.org/10.1159/000449036

Rosli, R., Capraro, M. M., \& Capraro, R. M. (2014). The effects of problem posing on student mathematical learning: A meta-analysis. International Education Studies, 7(13), 227-241. https://doi.org/10.5539/ies.v7n13p227

Sari, L. S. P., \& Rahadi, M. (2014). Pembelajaran Berbasis Masalah Untuk Meningkatkan Kemampuan Komunikasi Matematika Siswa Sekolah Menengah Pertama. Jurnal Pendidikan Matematika, 3(September), 151-158.

Sarifah, I. (2011). Pengaruh Penerapan Model Problem Based Learning terhadap Pencapaian Hasil Belajar (Suatu Meta Analisis terhadap Hasil Penelitian tentang Penerapan Problem Based Learning). Jurnal Ilmiah PGSD, 3(2), 2011.

Servant-Miklos, V. (2018). Fifty Years on: A Retrospective on the World's First Problem-based Learning Programme at McMaster University Medical School. Health Professions Education, 5(1), 3-12. https://doi.org/10.1016/j.hpe.2018.04.002

Siddaway, A. P., Wood, A. M., \& Hedges, L. V. (2019). How to Do a Systematic Review: A Best Practice Guide for Conducting and Reporting Narrative Reviews, Meta-Analyses, and Meta-Syntheses. Annual Review of Psychology, 70(1), 747-770. https://doi.org/10.1146/annurev-psych-010418102803

Surya, E., Syahpurta, E., \& Juniati, N. (2018). Effect of problem based learning toward mathematical communication ability and self-regulated learning. Journal of Education and Practice, 9(6), 14-23. https://doi.org/10.29103/mjml.v1i1.741

Syafrial, S. (2018). Meta-Analisis Cooperative Learning Terhadap Kemampuan Berpikir Kritis Pada Pembelajaran Ipa/ Fisika Siswa. Journal of Teaching and Learning Physics, 3(1), 27-33. https://doi.org/10.15575/jotalp.v3i1.6550

Tamur, M., \& Juandi, D. (2020). Effectiveness of Constructivism Based Learning Models Against Students Mathematical Creative Thinking Abilities in Indonesia; A Meta-Analysis Study. Mathematics, Science, and Computer Science Education International Seminar, MSCEIS 2019, 1-8. https://doi.org/10.4108/eai.12-10-2019.2296507

Tamur, M., Juandi, D., \& Adem, A. M. G. (2020). Realistic Mathematics Education in Indonesia and Recommendations for Future Implementation : A Meta-Analysis Study. Jurnal Teori Dan Aplikasi Matematika, 4(1), 17-27. https://doi.org/10.31764/jtam.v4i1.1786

Thorndahl, K. L., \& Stentoft, D. (2020). Thinking Critically About Critical Thinking and Problem-Based Learning in Higher Education: A Scoping Review. Interdisciplinary Journal of Problem-Based Learning, 14(1). https://doi.org/10.14434/ijpbl.v14i1.28773 
154 | JTAM (Jurnal Teori dan Aplikasi Matematika) | Vol. 4, No. 2, October 2020, pp. 145-154

Wang, J., \& Lin, E. (2009). A meta-analysis of comparative studies on Chinese and US students' mathematics performance: Implications for mathematics education reform and research. Educational Research Review, 4(3), 177-195. https://doi.org/10.1016/j.edurev.2009.06.003

Yanti, A. H. (2017). Penerapan Model Problem Based Learning (PBL) Terhadap Kemampuan Komunikasi dan Kemampuan Pemecahan Masalah Matematika Siswa Sekolah Menengah Pertama Lubuklinggau. Jurnal Pendidikan Matematika Raflesia, 1(1), 1-10. https://doi.org/10.1037/00223514.51.6.1173 